Hideo Iwasaka MD, Hiroshi Miyakawa MD, Hitoshi Yamamoto MD, Takaki Kitano MD, Kazuo Taniguchi MD, Natsuo Honda MD

\title{
Respiratory mechanics and arterial blood gases during and after laparoscopic cholecystectomy
}

Purpose: The purpose of this study was to assess the effects of increased intra-abdominal pressure due to $\mathrm{CO}_{2}$ insufflation on the mechanical characteristics of the respiratory system and arterial blood gases during and after laparoscopic cholecystectomy.

Methods: Respiratory mechanics and arterial blood gases were examined in 12 patients undergoing laparoscopic cholecystectomy with $\mathrm{CO}_{2}$ insufflation. Respiratory mechanics were continuously monitored with in-line spirometry. In the recovery room, $\mathrm{PaCO}_{2}$ was measured in this group at $30 \mathrm{~min}$ and compared with $\mathrm{PaCO}_{2} \mathrm{~s}$ in 23 patients who had undergone open cholecystectomy retrospectively, to evaluate the effects of insufflation on $\mathrm{CO}_{2}$ elimination.

Results: Minute ventilation was decreased by about 500 $\mathrm{ml} \cdot \mathrm{min}^{-1}$ during abdominal insufflation. Dynamic lung compliance decreased from $49.6 \pm 4.7$ to $30.7 \pm 2.3$ (mean $\pm S E M$ ) $\mathrm{ml} \cdot \mathrm{cmH}_{2} \mathrm{O}^{-1}$ with abdominal insufflation $(P<0.005)$, and returned to $45.1 \pm 3.1$ after the release of pneumoperitoneum. Peak inspiratory pressure increased from $15.9 \pm 0.9$ to $18.9 \pm$ $1.0 \mathrm{cmH}_{2} \mathrm{O}$ with abdominal insufflation $(P<0.05)$. Arterial blood gas determinations indicated a decrease in arterial $\mathrm{pH}$, with $\mathrm{CO}_{2}$ retention during insufflation and in the recovery room $(\mathrm{P}<0.05) . \mathrm{PaCO}_{2}$ of the laparoscopic patients was higher than that of the open patients in the recovery room.

Conclusion: The results indicate that respiratory acidosis was caused during $\mathrm{CO}_{2}$ insufflation for laparoscopic cholecystectomy, that was due to (I) decreased compliance, (2) increased $\mathrm{CO}_{2}$ load and (3) insufficient ventilation. Accumulated $\mathrm{CO}_{2}$

\section{Key words}

MONITORING: dynamic lung compliance, peak

inspiratory pressure, carbon dioxide tension; SURGERY: laparoscopic cholecystectomy.

From the Department of Anesthesiology, Oita Medical University, Oita, Japan

Address correspondence to: Dr. Hideo lwasaka,

Department of Anesthesiology, Oita Medical University, 1-1, Idaigaoka, Hasama-machi, Oita-gun, Oita 879-55, Japan.

Accepted for publication 21st September, 1995. during laparoscopic cholecystectomy increased $\mathrm{PaCO}_{2}$ level in the recovery room.

Objectif: Evaluer les effets de l'augmentation de pression intraabdominale provoquée par l'insufflation de $\mathrm{CO}_{2}$ sur les caractéristiques du système respiratoire et des gaz du sang artériel pendant et après la cholécystectomie laparoscopique. Méthode: La mécanique respiratoire et les gaz du sang artériels ont été étudiés chez 123 patients soumis à une cholécystectomie laparoscopique avec insufflation de $\mathrm{CO}_{2} . \mathrm{La}$ mécanique respiratore a été monitorée en continu par spirométrie. A la salle de réveil, la $\mathrm{PaCO}_{2}$ a été mésurée à la $30^{\circ}$ min de l'admission et comparée rétrospectivement à la $\mathrm{PaCO}_{2}$ de 23 patients qui avaient subi une cholécystectomie ouverte, dans le but d'évaluer les effets de l'insufflation sur l'élimination du $\mathrm{CO}_{2}$.

Résultats: La ventilation minute a diminué d'environ 500 $\mathrm{ml} \cdot \mathrm{min}^{-1}$ pendant l'insufflation abdominale. La compliance dynamique pulmonaire diminuait de 49,6 4 4,7 à $30,7 \pm 2,3$ (moyenne $\pm \mathrm{SEM}$ ) $\mathrm{ml} \cdot \mathrm{cm} \mathrm{H}_{2} \mathrm{O}^{-1}$ avec l'insufflation $(\mathrm{P}<0,005)$ et revenait à $45, I \pm 3,1$ après le relâchement du pneumopéritoine. L'analyse des gaz artériels a révélé une diminution du $\mathrm{pH}$ artériel avec rétention de $\mathrm{CO}_{2}$ pendant l'insufflation et à la salle de réveil $(P<0,005)$. La $\mathrm{PaCO}_{2}$ des patients opérés sous laparoscopie était plus élevée que celle des patients opérés par chirurgie ouverte.

Conclusion: Ces résultats indiquent que l'insufflation de $\mathrm{CO}_{2}$ pour la cholécystectomie laparoscopique provoque de l'acidose respiratoire causée 1) par la baisse de la compliance, 2) l'augmentation du volume de $\mathrm{CO}_{2}$ et 3) l'insuffisance ventilatoire. L'accumulation du $\mathrm{CO}_{2}$ pendant la cholécystectomie laparoscopique augmente la $\mathrm{PaCO}_{2}$ à la salle de réveil.

Laparoscopic cholecystectomy has gained worldwide acceptance because of shortened hospital stays and improved patient satisfaction. ${ }^{1,2}$ This surgical laparoscopic procedure involves change in patient position from supine to reverse Trendelenburg, and requires intraperitoneal carbon dioxide $\left(\mathrm{CO}_{2}\right)$ insufflation. 
Laparoscopic cholecystectomy may require longer periods of peritoneal insufflation than previously reported in gynaecological procedures. It is conceivable that the longer $\mathrm{CO}_{2}$ insufflation might impede diaphragmatic movement and increase the $\mathrm{CO}_{2}$ load for ventilation. ${ }^{3,4}$ Respiratory mechanics and blood gases must be monitored to identify the mechanical and ventilatory effects of insufflation.

However, the reverse Trendelenburg position may be accompanied by respiratory advantages, ${ }^{2}$ because arterial hypercapnia may be caused not only by the transperitoneal absorption of $\mathrm{CO}_{2}$ but also by the decreased dynamic lung compliance during laparoscopic cholecystectomy. ${ }^{3}$ To test this hypothesis, we assessed the effects of increased intra-abdominal pressure due to $\mathrm{CO}_{2}$ insufflation on the mechanical characteristics of the respiratory system and on arterial blood gas analysis during and after laparoscopic cholecystectomy. The effects of $\mathrm{CO}_{2}$ load during laparoscopic cholecystectomy on $\mathrm{PaCO}_{2}$ in the recovery room was compared with that in patients undergoing open cholecystectomy.

\section{Methods}

The study was approved by the Institutional Ethics Committee. Informed consent was obtained from 12 patients (eight women, four men) scheduled for laparoscopic cholecystectomy. Retrospective following-up of the anaesthesia records was also approved by the Ethics Committee. None had functionally limiting respiratory, cardiac, or metabolic disease. All were classified as American Society of Anesthesiology (ASA) physical status I.

All patients were premedicated with hydroxyzine (50 $\mathrm{mg}$ ) and atropine $(0.5 \mathrm{mg})$ im $30 \mathrm{~min}$ before transfer to the operating theatre. Anaesthesia was induced with thiamylal sodium (4-5 $\mathrm{mg} \cdot \mathrm{kg}^{-1}$ ). Vecuronium bromide $\left(0.1-0.15 \mathrm{mg} \cdot \mathrm{kg}^{-1}\right)$ was given for muscle relaxation. After tracheal intubation, general anaesthesia was maintained with $60 \%$ nitrous oxide in oxygen and sevoflurane (1.0-2.0\%) as needed. Adequate muscle relaxation was achieved by incremental injection of vecuronium when the train-of-four ratio, which was monitored by the force of contraction of the adductor pollicis, exceeded $75 \%$. The lungs were mechanically ventilated with the same volume-cycled ventilator using a semi-closed circle system incorporating a carbon dioxide absorber (NARKOMED 2B). The ventilator was inspected for leaks before each case and the same type of disposable breathing tubing was used throughout the study. Tidal volume was set at $10 \mathrm{ml} \cdot \mathrm{kg}^{-1}$, with a rate of 10 breaths- $\mathrm{min}^{-1}$. This was maintained throughout the study period. An Ultima SV respiratory in-line monitor (Datex Instrumentarium Corp, Helsinki, Finland) was
TABLE I Data on patients

\begin{tabular}{lll}
\hline & $\begin{array}{l}\text { Laparoscopic } \\
\text { cholecystectomy }\end{array}$ & $\begin{array}{l}\text { Open } \\
\text { cholecystectony }\end{array}$ \\
\hline$n$ & 12 & 23 \\
Age (yr) & $50.8 \pm 3.4$ & $55.1 \pm 2.8$ \\
Weight (kg) & $57.0 \pm 3.5$ & $57.7 \pm 1.7$ \\
Sex (M/F) & $4 / 8$ & $9 / 14$ \\
Duration of anaesthesia (min) & $142.5 \pm 10.1$ & $134.3 \pm 8.8$ \\
Duration of operation (min) & $110.8 \pm 8.9$ & $97.6 \pm 6.1$ \\
\hline
\end{tabular}

Data are mean \pm SEM. For any variables, $P>0.05$.

used to collect respiratory data. ${ }^{5}$ This monitor, which undergoes regular maintenance and calibration, analyses respiratory gases (inspiratory and expiratory oxygen and carbon dioxide concentrations) and ventilatory variables (expiratory tidal volume, dynamic lung compliance, peak and plateau inspiratory pressure $).\left(\mathrm{O}_{2}\right.$ linearity: $<2 \%, \mathrm{CO}_{2}$ linearity: $<2 \%$, airway pressure error: \pm 1.5 $\mathrm{cmH}_{2} \mathrm{O}$, tidal volume error: $\pm 6 \%$ ). These values were displayed breath-by-breath. Arterial blood gas samples were analyzed immediately using an infrared spectrometer (ABL-3, Radiometer Inc, West Lake, Ohio), which was autocalibrated regularly (two point calibration every four hours, one point calibration every two hours). The measurements were made just before (approximately $15 \mathrm{~min}$ after induction of anaesthesia), and one hour after the establishment of a pneumoperitoneum with the patient positioned in the reverse Trendelenburg $\left(10^{\circ}\right)$ position with a left tilt $\left(5^{\circ}\right)$. Measurements were also made just after abdominal desufflation with the patient in the supine position. Arterial blood was also sampled in the recovery room (30 min after tracheal extubation). Carbon dioxide was used for peritoneal insufflation, and abdominal pressure was maintained at 8 to $10 \mathrm{mmHg}$.

We also compared, retrospectively, the $\mathrm{PaCO}_{2}$ in the recovery room (30 min after tracheal extubation) in similar unselected patients ( $n=23$, ASA physical status I) who had undergone open cholecystectomy to examine the effects of insufflation on $\mathrm{CO}_{2}$ elimination.

Results are reported as the mean \pm SEM. The effects of successive steps in the procedure were evaluated by one-way ANOVA and Fisher's Protected Least Significant Difference. Linear regression analysis was performed by the method of least squares. Comparison between end-tidal and arterial $\mathrm{CO}_{2}$ was performed with the Bland and Altman method. ${ }^{6}$ Significance was assumed at the $P<0.05$ level.

\section{Results}

As shown in Table $I$, there was no differences in age, 
TABLE II Effects of carbon dioxide insufflation on respiratory mechanics during laparoscopic cholecystectomy

\begin{tabular}{|c|c|c|c|}
\hline & Pre-insufflation & I hr after insufflation & Post-desufflation \\
\hline Dynamic lung compliance $\left(\mathrm{ml} \cdot \mathrm{H}_{2} \mathrm{O}^{-1}\right)$ & $49.6 \pm 4.7$ & $30.7 \pm 2.3^{* *}$ & $45.1 \pm 3.1 \dagger$ \\
\hline Peak inspiratory pressure $\left(\mathrm{cmH}_{2} \mathrm{O}\right)$ & $15.9 \pm 0.9$ & $18.9 \pm 1.0^{*}$ & $17.5 \pm 1.3$ \\
\hline Inspiratory plateau pressure $\left(\mathrm{cmH}_{2} \mathrm{O}\right)$ & $13.2 \pm 1.1$ & $17.4 \pm 1.1 * *$ & $14.9 \pm 1.0$ \\
\hline Expiratory tidal volume (ml) & $543.3 \pm 33.4$ & $496.5 \pm 37.7$ & $546.2 \pm 33.3$ \\
\hline $\mathrm{PaCO}_{2}(\mathrm{mmHg})$ & $34.5 \pm 0.7$ & $42.8 \pm 1.0^{* *}$ & $37.5 \pm 1.1 \dagger$ \\
\hline End-tidal $\mathrm{CO}_{2}(\mathrm{mmHg})$ & $34.0 \pm 0.8$ & $42.5 \pm 1.4^{* *}$ & $37.3 \pm 1.1 \dagger$ \\
\hline Pa-PErCO $(\mathrm{mmHg})$ & $0.06 \pm 0.47$ & $0.24 \pm 0.49$ & $0.01 \pm 0.56$ \\
\hline
\end{tabular}

*Compared with.pre-insufflation (*P<0.01, **P<0.005)

†Compared with 1 hour after insufflation $(\dagger P<0.0$ I)

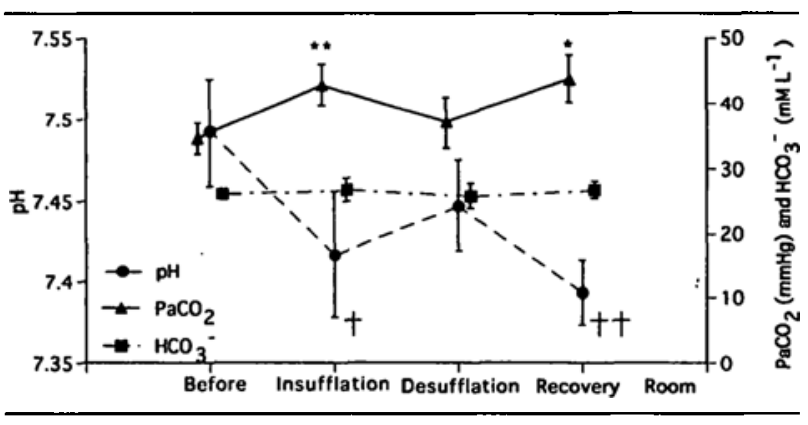

FIGURE 1 Changes in arterial blood $\mathrm{pH}$, carbon dioxide tension $\left(\mathrm{PaCO}_{2}\right)$, bicarbonate concentration $\left(\mathrm{HCO}_{3}{ }^{-}\right)$during laparoscopic cholecystectomy. Pre: prior to insuffation, Insufilation: 1 hour after establishment of pneumoperitoneum, Desufflation: just after release of pneumoperitoneum, Recovery Room: $30 \mathrm{~min}$ after tracheal extubation. Significant differences compared with pre-insufflation $(* P<$ $0.05, * * P<0.01,+P<0.005,+\dagger P<0.001$ ).

weight, sex, anaesthesia or operation time between laparoscopic and open cholecystectomy patients.

Peritoneal insufflation decreased the dynamic lung compliance compared with pre-insufflation and postdesufflation values (Table II). Both peak and plateau inspiratory pressures were increased with insufflation compared with baseline. The expiratory tidal volume was.not decreased with insufflation.

All patients maintained adequate oxygen saturation during the sludy. However, arterial and end-tidal carbon dioxide tensions increased during insufflation compared with pre-insufflation and decreased with desufflation. Blood gas analysis revealed a decrease in arterial $\mathrm{pH}$ and an increase in arterial carbon dioxide tension $\left(\mathrm{PaCO}_{2}\right)$ with insuftlation compared with pre-insufflation. These values returned toward normal after desufflation, but were again abnormal in the recovery room (Figure 1). Bicarbonate concentration was constant throughout the study. Increases in individual patient $\mathrm{PaCO}_{2}$ measurements were accompanied by corresponding increases in simultaneously obtained end-tidal $\mathrm{CO}_{2}$ measurements ( $r=0.937, P<0.0001$ ). Results with the

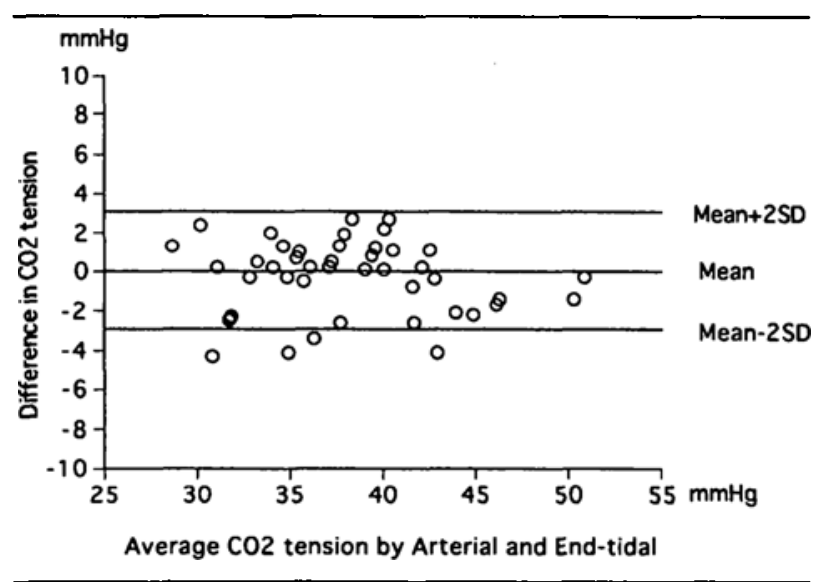

FIGURE 2 Scatterplot of differences ( $y$ axis) and average ( $x$ axis) of end-tidal and arterial $\mathrm{CO}_{2}$ during laparoscopic cholecystectomy. Horizontal lines indicate the mean difference $\pm 2 \mathrm{SD}$ ( $95 \%$ conlidence limits of agreement) between end-tidal and arterial $\mathrm{CO}_{2}$.

Bland-Altman method are shown in Figure 2. The mean difference between end-tidal and arterial $\mathrm{CO}_{2}$ was $0.3 \pm$ $0.3 \mathrm{mmHg}$ (range -4.3 to 2.7 ). There was a high negative correlation between the perioperative change in $\mathrm{pH}$ and $\mathrm{PaCO}_{2}(r=-0.789, P<0.0001)$.

The $\mathrm{PaCO}_{2}$ in the recovery was higher in patients who had undergone laparoscopic cholecystectomy than in those who had an open cholecystectomy $(44.6 \pm 1.1$ vs $38.4 \pm 1.0 \mathrm{mmHg}, P<0.0004$ ).

\section{Discussion}

This study shows that dynamic lung compliance decreased and arterial as well as end-tidal $\mathrm{PCO}_{2}$ increased during insufflation. The values returned to baseline after release of pneumoperitoneum but the $\mathrm{PaCO}_{2}$ increased again in the recovery room to levels which were higher than those seen after open cholecystectomy.

During laparoscopic procedures, pneomoperitoneum may cause respiratory embarrassment due to the 
mechanical effect of the increased intra-abdominal pressure. ${ }^{7,8}$ Dynamic lung compliance was reduced by about $40 \%$ with increased peak inspiratory and inspiratory plateau pressures during insufflation. Abdominal distension may impede the movement of diaphragm and restrict lung expansion. The increase in airway pressure we observed in the presence of adequate muscle relaxation reflects the decrease in compliance associated with the elevated intra-abdominal pressure. ${ }^{3}$ We assume that the decrease in dynamic lung compliance is due to cephalad shift of the diaphragm caused by the insufflated gas during the procedure. ${ }^{9}$

With the increased intra-abdominal pressure and the cephalad shift of the diaphragm, increased airway pressures are needed to maintain a constant minute ventilation. In this study, the value of the expiratory tidal volume decreased by $50 \mathrm{ml}$ at insufflation. The circuit losses from stretching can be $6 \mathrm{ml} \cdot \mathrm{H}_{2} \mathrm{O}^{-1} .{ }^{10}$ Thus, with an airway pressure of $40 \mathrm{mmHg}, 240 \mathrm{ml}$ or more may be lost due to circuit distension. In a small patient with a high intra-abdominal pressure during laparoscopy, this may exceed the tidal volume. Loss of about $50 \mathrm{ml}$ per breath is equal to $500 \mathrm{ml} \cdot \mathrm{min}^{-1}$ cumulative loss which, together with the calculated loss due to tube distension, may cause insufficient ventilation. This may result in $\mathrm{CO}_{2}$ retention. Therefore, it is important to use continuous in-line spirometry for routine intraoperative monitoring during laparoscopic cholecystectomy.

Although laparoscopic cholecystectomy is purported to be minimally invasive, ${ }^{11-13}$ uptake of $\mathrm{CO}_{2}$ from the pneumoperitoneum can cause clinically relevant hypercapnia. In this prospective study, monitoring of respiratory mechanics did not reveal a change in the expiratory tidal volume. Hence, we concluded that the carbon dioxide retention we observed was mainly the result of the pneumoperitoneum. Associated with this hypercapnia was a decrease in arterial $\mathrm{pH}$. These changes in $\mathrm{pH}$ and $\mathrm{PaCO}_{2}$ were well correlated. Because bicarbonate concentration did not change throughout the study, the decrease in $\mathrm{pH}$ was not metabolic. Blobner et al. have also reported an increased $\mathrm{CO}_{2}$ load (40\%) during pneumoperitoneum, which was felt to be caused by resorption of $\mathrm{CO}_{2}$ from the abdominal cavity. ${ }^{4}$ Thus the need for careful monitoring of respiratory function, especially the extent of $\mathrm{CO}_{2}$ retention is clear. However, one of the most controversial issues regarding the management of patients during laparoscopy is whether radial arterial cannulation should be performed to assess the degree of hypercapnia and the effectiveness of oxygenation. ${ }^{14.15}$ In our study of healthy patients with mechanical ventilation, end-tidal $\mathrm{CO}_{2}$ and $\mathrm{PaCO}_{2}$ were well correlated. The mean difference between end-tidal and arterial $\mathrm{PCO}_{2}$ was also small in our study. These results suggest that end-tidal $\mathrm{PCO}_{2}$ monitoring is sufficient in this patient population. In contrast, patients with cardiac or pulmonary disease have exhibited differences between $\mathrm{PaCO}_{2}$ and end-tidal $\mathrm{PCO}_{2}{ }^{15}$ Therefore, radial artery cannulation for frequent arterial blood gas analysis should be considered in patients with preoperative cardiopulmonary disease.

Both $\mathrm{PaCO}_{2}$ and $\mathrm{pH}$ immediately recovered to preinsufflation values with the release of the pneumoperitoneum. Following the successful completion of the laparoscopic cholecystectomy, neuromuscular blockade was reversed with neostigmine $(2 \mathrm{mg})$ and atropine (1 $\mathrm{mg}$ ), which was followed by tracheal extubation. Of particular interest was the observation that $\mathrm{PaCO}_{2}$ was increased and $\mathrm{pH}$ was decreased again in the recovery room. In addition, the $\mathrm{PaCO}_{2}$ in the recovery room was higher in patients who underwent laparoscopic than after open cholecystectomy. This indicates that the hypercapnia induced by pneumoperitoneum persists after extubation as the carbon dioxide is gradually eliminated from the tissue. In our group, the operative time was long, almost double that noted in a recent report. ${ }^{17}$ This prolonged operative time might increase absorbed $\mathrm{CO}_{2}$ during insufflation, which may influence the second increase of $\mathrm{CO}_{2}$ in the recovery room. Although laparoscopic cholecystectomy has many advantages, particularly minimal effects on respiratory function, ${ }^{18}$ diaphragmatic function was inhibited in the early postoperative period. ${ }^{19,20}$ Impaired diaphragmatic function immediately after laparoscopic surgery may also cause hypercapnia early in the recovery room period. Furthermore, subcutaneous emphysema, which is one of the most important complications, can increase endtidal $\mathrm{PCO}_{2}{ }^{21}$ Fortunately, we could find no emphysematous complication during this study. In the anaesthetic management of the laparoscopic cholecystectomy, hypercapnia after tracheal extubation must be considered.

In summary, insufflation of the abdominal cavity with carbon dioxide during laparoscopic cholecystectomy has several consequences including decreased lung compliance, decreased expiratory minute volume, and high peak airway pressures. Hypercarbia and acidosis were due to (1) absorption of $\mathrm{CO}_{2}$ via the peritoneum, (2) decreased lung compliance and (3) insufficient ventilation. The hypercarbia and acidosis may persist in the recovery room. The anaesthetist should carefully observe and document respiratory mechanics and arterial blood gases in these patients.

\section{Acknowledgement}

We would like to acknowledge the assistance of our anaesthesiologists and the operating theatre staff. 


\section{References}

I Rose DK, Cohen MM, Soutter DI. Laparoscopic cholecystectomy: the anaesthetist's point of view. Can J Anaesth 1992; 39: 809-15.

2 Cunningham AJ, Brull S.J. Laparoscopic cholecystectomy: anesthetic implications. Anesth Analg 1993; 76: 1120-33.

3 Bardoczky GI, Engelman E, Levarlet M, Simon $P$. Ventilatory effects of pncumoperitoneum monitored with continuous spirometry. Anacsthesia 1993; 48: 309-11.

4 Blobner M. Felber AR, Gögler $S$, et al. Zur resorption von kohlendioxid aus dem pneumoperitoneum bei laparoskopischen cholezystektomien. Anaesthesist 1993; 42 : 288-94.

5 Bardockzy GI, d'Hollander A. Continuous monitoring of the flow-volume loops and compliance during anesthesia. J Clin Monit 1992; 8: 251-2.

6 Bland JM, Allman DG. Statistical methods for assessing agreement between two methods of clinical measurement. Lancet 1986; February 8: 307-10.

7 Desmond $J$, Gordon RA. Ventilation in patients anaesthetized for laparoscopy. Can Anacsth Soc J 1970; 17: 378-87.

8 Ohlgisser M, Sorokin Y, Heifetz M. Gynecologic laparoscopy. A review article. Obstet Gynecol Surv 1985; 40: 385-96.

9 Wahba RWM, Béique F, Kleiman SJ. Cardiopulmonary function and laparoscopic cholecystectomy. Can J Anaesth 1995; 42: 51-63.

10 Benumof $J L$. Anesthesia for pulmonary surgery. 1991 Annual ASA Refresher Course Lectures 1991; 225: 1-7.

11 Dubois F, Icard P, Berthelot $G$, Levard H. Coelioscopic cholecystectomy. Ann Surg 1990; $211:$ 60-2.

12 Reddick EJ, Olsen DO. Outpatient laparoscopic laser cholecystectomy. Am J Surg 1990; 160: 485-7.

13 Luiz $T$, Huber $T$, Hartung $H-J$. Veränderungen der ventilation während laparoskopischer cholezystektomie. Anaesthetist 1992; 41: 520-6.

14 Yamanaka $M K$, Sue $D Y$. Comparison of arterial-end-tidal $\mathrm{PCO}_{2}$ difference and dead space/tidal volume ratio in respiration failure. Chest 1987; 92: 832-5.

15 Liu S-Y, Leighton T, Davis I, Klein S, Lippmann M, Bongard $F$. Prospective analysis of cardiopulmonary responses to laparoscopic cholecystectomy. J Laparoendosc Surg 1991; 1: 241-6.

16 Wittgen $C M$, Andrus $C H$, Fitzgerald $S D$, Baudendistel $L$, Dahms TE, Kaminski DL. Analysis of the hemodynamic and ventilatory effects of laparoscopic cholecystectomy. Arch Surg 1991; 126: 997-1001.

17 McMahon AJ, Russel IT, Baxter JN, et al. Laparoscopic versus minilaparotomy cholecystectomy: a randomized trial. Lancet 1994; 343: 135-8.

18 Joris I, Cigarini $M$, Legrand $M$, et al. Metabolic and respiratory changes after cholecystectomy performed via laparotomy or laparoscopy. Br J Anaesth 1992; 69: $341-5$.

19 Erice F, Fox GS, Salib YM, Romano E, Meakins JL, Magder SA. Diaphragmatic function before and after laparoscopic cholecystectomy. Anesthesiology 1993; 79 : 966-75.

20 Couture JG, Chartrand D, Gagner $M$, Bellemare $F$. Diaphragmatic and abdominal muscle activity after endoscopic cholecystectomy. Anesth Analg 1994; 78: 733-9.

21 Lew $J K L$, Gin $T$, Oh TE. Anaethetic problems during laparoscopic cholecystectomy. Anaesth Intensive Care 1992; 20: 91-2. 